Research Article

\title{
The Effect of Investment on Poverty with Economic Growth as An Intervening Variables in Central Sulawesi
}

\author{
Christina Shandra Tobondo $^{{ }^{*}}$, Djayani Nurdin², Eko Jokolelono ${ }^{2}$ \\ ${ }^{1}$ Doctoral Study Program of Economics, Tadulako University, Indonesia \\ ${ }^{2}$ Faculty of Economics and Business, Tadulako University, Indonesia
}

Article Information
Received: 29 November 2020
Revised version received: 05 January 2021
Accepted: 07 January 2021
Published: 25 January 2021
Cite this article as:
C.S. Tobondo et al. (2021) Int. J. Soc. Sc. Manage.
8(1): 320 -332. DOI: $10.3126 /$ ijssm.v8i1.34127

\section{*Corresponding author}

Christina Shandra Tobondo,

Doctoral Study Program of Economics, Tadulako

University, Indonesia

Email: hernida.hi.kone10@gmail.com

Peer reviewed under authority of IJSSM

(C) 2021 IJSSM, Permits unrestricted use under the CC-By-NC license.

\section{OPEN ACACESS}

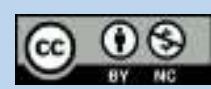

This is an open access article $\&$ it is licensed under a Creative Commons Attribution Non-Commercial 4.0 International

(https://creativecommons.org/licenses/by-nc/4.0/)

Keywords: Investment; Economic Growth; Poverty

\begin{abstract}
This study aims to analyze the direct and indirect effects of foreign investment (PMA), domestic investment (PMDN), and government investment on poverty levels through economic growth in Central Sulawesi Province. Research explanations (explanatory research) will prove a causal relationship between the independent variable (independent variable) foreign direct investment (FDI), investment in the country (domestic), and government investment, with poverty as the dependent variable (dependent variable) with a variable economic growth as a variable intervening. The type of data used in this study is panel data (pooled data). The sampling method used purposive sampling technique. Using SEM (Structural Equation Modeling) analysis tools with the PLS (Partial Least Square) approach. The results of the first hypothesis show that there is a direct influence between foreign investment (PMA) and government investment on poverty levels in Central Sulawesi, but there is no direct influence between domestic investment (PMDN) on poverty levels in Central Sulawesi. The second hypothesis testing shows that there is an indirect effect between foreign investment, domestic investment, and government investment on poverty levels through economic growth in Central Sulawesi. Efforts to increase economic growth and reduce poverty in Central Sulawesi can be carried out through the creation of a conducive social, political, legal, and bureaucratic system, the realization of investment that is directly correlated with economic programs to alleviate poverty, and maximize the use of Corporate Social Responsibility funds. (CSR) by local governments through the body of the APBD.
\end{abstract}

\section{Preliminary}

The phenomenon of globalization is inevitable, something that is certain to happen, in addition to providing economic benefits but also bringing implications on many aspects of human life, which ultimately requires society to adapt to the changes that occur. For example, changes in the flow of international trade make products created by countries on other continents that can be consumed by the people, even in remote cities/villages on other continents. International capital flows have implications for the transfer of industry in developed countries to developing countries to obtain cheap labor. Changes in information technology allow international news to be known to the whole world in just a few moments. The liberalization of national and global markets opens the door as wide as possible for the entry of 
various products and services for consumers in a country. Finally, globalization also changes people's thinking and behavior (Yuniarto, 2014).

This globalization is characterized by the emergence of various phenomena such as the high level of mobility of resources, especially investment which causes high dependence between communities, increasingly tighter and free competition, and an increasingly rapid flow of information change. This phenomenon encourages the state to open economic cooperation, especially investment, both in regional and international scope in the form of Foreign Investment (PMA) and Domestic Investment (PMDN).

In 2017, Indonesia has achieved investment-grade ratings from three international rating agencies (Standard \& Poors, Moody's Investors Service, and Fitch Ratings). This is expected to increase the interest of foreign direct investment in Indonesia, in line with increasing investor confidence. Research conducted by Nosheen (2013) entitled Impact of Foreign Direct Investment on Gross Domestic Product found that PMA plays a role in increasing economic growth in Pakistan. By using cointegration analysis, this study found the results of a long-term relationship between PMA and increased economic growth.

Apart from foreign investment, economic growth is also supported by domestic investment (PMDN). PMDN is an investment activity to conduct business in the territory of the Republic of Indonesia which is carried out by Domestic Investors using domestic capital (BKPM, 2017). The results of Bouchoucha and Bakari's (2019) research conducted by analyzing the impact of domestic investment (PMDN) and foreign investment (PMA) on economic growth in Tunisia during the period 1976-2017, which was based on the AutoRegressive Distributive Lags (ARDL) approach, concluded that PMDN has a negative effect on economic growth in the long term, but in the short term PMDN causes economic growth.

Private investment, both PMA and PMDN, is highly expected to sustain economic growth, although government investment is also highly expected. Government spending is part of fiscal policy, namely a government action to regulate the running of the economy by determining the amount of government revenue and expenditure each year. A study on government investment has been carried out by Rabnawaz and Jafar (2015) in Pakistan. The study examines the relationship between GDP and government investment. The data series used in the study covers the period 1980 2009. The causality test Granger used to see whether there is a relationship between GDP by investigation government. The results show that there is a positive relationship between GDP and government investment in the short term. An increase in GDP leads to an increase in government investment.
Central Sulawesi Province is one of the developing regions that need investment to increase its economic growth. Data on macroeconomic growth in Central Sulawesi Province for the period 2016 - 2018 shows that the amount of foreign investment and government investment continued to decline from 2016 to 2018. In 2016, the amount of foreign investment in Central Sulawesi was recorded at Rp. 21.91 trillion, down to Rp. 20.63 trillion or $5.84 \%$ in 2017 , and decreased to Rp. 9.01 Trillion or $56.32 \%$ in 2018 . In the same period, the amount of government investment through regional spending also saw a decline. In 2016, the total government investment was Rp. 22.99 Trillion, which decreased to Rp. 22.56 Trillion or $1.87 \%$ in 2017 and the realization of government spending decreased to Rp. 21.70 Trillion or $3.81 \%$ in 2018 .

However, the decline in the amount of foreign investment (PMA) and government investment did not affect the interest of local investors to invest in Central Sulawesi. Central Sulawesi Province DPMPTSP in 2019 recorded an increase in the amount of domestic investment in Central Sulawesi for the 2016-2017 period. In 2016, the amount of PMDN investment was recorded at Rp. 1.08 trillion, increased to Rp. 1.93 Trillion or $78.7 \%$ in 2017, and increased to Rp. 12.69 trillion or $571.5 \%$ in 2018.

This condition is inversely proportional to the slowdown in economic growth in the same period. Central Sulawesi Province DPMPTSP recorded an economic growth rate in Central Sulawesi in 2016 of $9.98 \%$, decreased to $7.14 \%$ in 2017 , and decreased to $6.30 \%$ in 2018 . Based on the data above, an interesting phenomenon that when the amount of investment and economic growth slows down, there is an increase in the welfare of the community (a decrease in the poverty rate). DPMPTSP Central Sulawesi Province recorded that the poverty rate in Central Sulawesi in 2016 was $14.45 \%$, decreased to $14.14 \%$ in 2017 , and decreased to $14.01 \%$ in 2018 . This is per the results of research by Ebunoluwa and Yusuf (2018) which states that economic growth has an impact on reducing the poverty rate

Based on the phenomena that have been described, theories, and previous studies regarding investment, economic growth, and poverty, the researchers argue that there is still a need for theory development in responding to the above phenomena. The development of this theory is to modify the economic growth variable as an intervening variable with investment and poverty. The purpose of this study is to obtain empirical evidence regarding the direct and indirect effects of foreign investment (PMA), domestic investment (PMDN), and government investment on poverty levels through economic growth in Central Sulawesi Province.

\section{Literature Review}

Investment is the expenditure shown to increase or maintain the stock of capital goods. Stocks of capital goods consists of a factory, office machinery, and durable products more 
used in the production process (in Lailan and Sri Endang, 2011).

Investments that are prioritized in a country or region are determined by the interest rate, the predicted rate of investment returns, the level of national income and its changes, technological advances, and the profits obtained by the company (Sukirno, 2012). Explains that GDP measures the market value of the final goods and services produced by resources that are in a country for a certain period time, usually one year. GDP can also be used to study the economy over time or to compare several economies at a time. Investment is the most volatile element of GDP, so when spending on goods and services falls during a recession, most of the decline is associated with a fall in investment spending. Rudriger (Syahputra, 2017)

\section{Foreign Investment (PMA)}

Foreign Investment is an individual foreign citizen, a foreign business entity, and or a foreign government investing in the territory of the Republic of Indonesia. Regulation of the Investment Coordinating Board of the Republic of Indonesia (BKPM, 2017), article 1 paragraph 6 explains that foreign investment, hereinafter abbreviated as PMA, is an activity of investing to do business in the territory of the Republic of Indonesia which is carried out by foreign investors, both using capital. wholly foreign or jointly with Domestic Investors.

Law number 1 of 1967 and Law number 11 of 1970 concerning PMA also explain that what is meant by foreign investment (PMA) is a direct foreign investment that is carried out according to or based on provisions. This law and the one used to run a company in Indonesia, in the sense that the owner of the capital directly bears the risk of the investment. Meanwhile, the definition of foreign capital includes:

1. Foreign payment instruments that are not part of Indonesia's foreign exchange assets, which with the government's approval are used to finance companies in Indonesia.

2. Equipment for companies, including new inventions owned by foreigners and materials imported from abroad into Indonesian territory as long as these tools are not financed from Indonesian assets.

Portions of the proceeds of the company which are based on this law are permitted to be transferred but are used to finance companies in Indonesia.

\section{Domestic Investment (PMDN)}

Law Number 25 of 2007 Article 1 states that the definition of domestic capital is capital owned by the Republic of Indonesia, an individual Indonesian citizen, or a business entity in the form of a legal entity or not. The Indonesian Investment Coordinating Board (BKPM, 2017) explains that Domestic Investment is an individual Indonesian citizen, an Indonesian Business Entity, the Republic of Indonesia, or a region that invests in the territory of the Republic of Indonesia.

Regulation of the Investment Coordinating Board of the Republic of Indonesia (BKPM. 2017), article 1 paragraph 5 explains that domestic investment, hereinafter referred to as PMDN, is an activity of investing to do business in the territory of the Republic of Indonesia which is carried out by domestic investors using capital domestically. Private parties owning domestic capital as referred to in paragraph 1 of this article may consist of individuals and/or legal entities established under the applicable laws in Indonesia.

Based on the above understanding, it can be concluded that domestic investment is an investment activity carried out by investors using domestic capital in the territory of Indonesia.

\section{Government Investment}

It is not enough for the government to only achieve the ultimate goal of each of its spending policies, but also to take into account the intermediate targets who will enjoy or be affected by the policy. Increasing expenditures with the sole purpose of increasing national income or expanding employment opportunities are not sufficient but must take into account who (which strata of society) works or increases their income. The government also needs to avoid increasing its role in the economy which weakens the activities of the private sector (Dumairy, 2006).

Rostow and Musgrave stated that the connection between the development of government spending and the stages of economic development is distinguished between the initial stage, the intermediate stage, and the advanced stage. In the early stages of economic development, the percentage of government investment to total investment is large because at this stage the government must provide infrastructure such as education, health, transportation infrastructure, and so on. In the middle stage of economic development, government investment is still needed to increase economic growth so that it can take off, but at this stage, the role of private investment is getting bigger. The role of government remains large at the intermediate stage, therefore increasing the role of the private sector is much cause failure of the market, and also led the government should provide public goods and services in greater numbers and better quality. also, besides at this stage, economic development causes relations between sectors to become increasingly complicated (complicated). For example, the economic growth caused by the development of the industrial sector, the higher the level of air and water pollution, and the government must step in to regulate and reduce the negative impact of this pollution on society. The government must also protect workers who are in a weak position to improve their welfare. Musgrave states that in a development process, the ratio of private investment as a percentage of 
GNP will increase and the percentage of government investment as a percentage of GNP will be smaller. (Yuliarti, 2020).

At a further economic level, Rostow argues that economic development and government activities shift away from providing infrastructure for spending for social activities such as old-age welfare programs, health service programs, and so on (Yuliarti, 2020). In any country, there is always government interference or investment in the economy. In the modern economy, the role of government can be classified into 3 major groups, namely:

1. The role of allocation, namely the role of the government in the allocation of economic resources.

2. The role of distribution.

3. The role of stabilization (Yuliarti, 2020)

\section{Economic Growth}

Economic growth is the development of an economic activity that prevails from time to time and causes real national income to grow. The economic growth rate indicates the percentage increase in real national income on a tear, particularly when compared with the real national income in tear before (Sukirno, 2012a).

Continued rapid economic growth allows the industrialized nations to give more to their citizens, more resources for health care and pollution control, universal education for children, and public pensions.

Untoro (2010) explains that economic growth is the development of activities in the economy that causes goods and services produced in society to increase and the welfare of society to increase in the long term. Economic growth can also be interpreted as an increase in the long-term capacity of the country concerned to provide various economic goods to its residents (Sukirno, 2012b).

The purpose of economic growth is to assess the extent to which the development of a region has been successful in a certain period of time as seen from the GDP growth at constant prices (BPS, 2003). Arsyad, Lincolin (2010) states that economic growth is an increase in GDP / PNB regardless of whether the increase is greater or less than the population growth rate or whether the increase is greater or less than the population growth rate or whether changes in economic structure occur or not.

\section{Poverty}

Poverty is a condition that is often associated with needs difficulties, and deprivation in various situations of life. Poverty is the failure to function some basic capabilities or in other words, someone is said to be poor if he lacks opportunities to achieve/get these basic capabilities. Poverty should not be considered only as low income (low income) but must be considered as a capability handicap (Nizar et al., 2013). Kuncoro (2006) explains that the definition of poverty is the inability to meet the minimum standard of living. There are two kinds of measures of poverty, namely absolute poverty and relative poverty. Absolute poverty is the inability of a person to exceed the defined poverty line, while relative poverty is related to differences in the income level of one group compared to other groups.

The term poverty arises when a person or group of people is unable to meet a level of economic prosperity which is considered the minimum requirement for a certain standard of living. In developing countries, poverty is usually associated with problems of prosperity (welfare economics) which refers to the consumption of goods and services (Kuncoro, 2006).

Sharp (Kuncoro, 2006) tries to identify the causes of poverty from an economic perspective, namely:

1. Poverty arises because of the unequal patterns of resource ownership which result in an unequal distribution of income.

2. Poverty arises from differences in the quality of human resources.

3. Poverty arises due to differences in access to capital.

These three causes of poverty lead to the theory of the vicious cycle of poverty. The existence of underdevelopment, market imperfection, and low capital productivity. Low productivity results in the low income they receive. Low income will imply low savings and investment. Low investment results in underdevelopment. The logic is that a country is poor because he is poor.

\section{Research Methods}

This research is explanatory research which will prove the causal relationship between the independent variable, namely the foreign investment variable (PMA), domestic investment (PMDN) and government investment, and the dependent variable, namely poverty, and the dependent variable. economic growth as an intervening variable. The type of data used in this study is secondary data in the form of panel data (pooled data) concerning the value of the foreign investment, PMDN, government investment, economic growth, and poverty, from 2015 to 2019, as well as cross-section data consisting of 13 districts/cities in Central Sulawesi Province which resulted in 65 observations. The data analysis method used in this research is SEM (Structural Equation Modeling) with the PLS (Partial Least Square) approach. The parameter estimates obtained by PLS can be categorized into 3 (three). First, the weight estimate used to create a latent variable score is obtained based on how the inner model (a structural model that connects between latent variables) and the outer model (the measurement model, namely the relationship between the indicator and its construct) is specified with the residual variance results of the dependent variable latent variables 
and indicators) are minimized. Second, it reflects the path estimate that connects latent variables and between latent variables and the indicator block (loading). Third, it relates to the mean and location parameters (regression constant values) for indicators and latent variables. PLS uses a 3 (three) stage iteration process to obtain these three estimates. The first stage produces a weight estimate, the second stage produces an estimate for the inner model and outer model, and the third stage produces an estimate of the mean and location (constant). The steps to take:

1. Structural Model or Inner Model

2. Measurement Model or Outer Model

3. Constructing Path Diagram

4. Converting the Path Diagram to a System of Equations

5. Model Fit and Quality Indices

6. Resampling Bootstrapping

7. Testing Intervening Variables

\section{Research Results}

\section{Partial Least Square Analysis}

1. Evaluation of the measurement model / Measurement (Outer Model)
The results of the outer model on formative indicators can be seen in the Fig. 1.

The results of three fit indicators above, namely the average path coefficient (APC), average R-squared (ARS), and average variance inflation factor (AVIF). The output results show that the criteria for the goodness of fit model have been met, namely with an APC value of 0.328 and an ARS of 0.508 and significant. The AVIF value of 1.205 as an indicator of multicollinearity has also met the requirements. The result of the GoF calculation is 0.713 . This shows that the model obtained is good for making predictions. This means that the model has a high ability in explaining empirical data, besides that all the assumptions of WarpPls have been fulfilled so that the PLS model obtained is good.

To evaluate the feasibility of measuring formative latent variables, it can be seen from the Weight Indicator test.

In Table 1, it can be seen that there are no variable indicators that have a VIF value above a value of 3.3 and a P-value $<0.05$ for all indicators. So that it can be concluded that the formative data in the research are feasible to be tested.

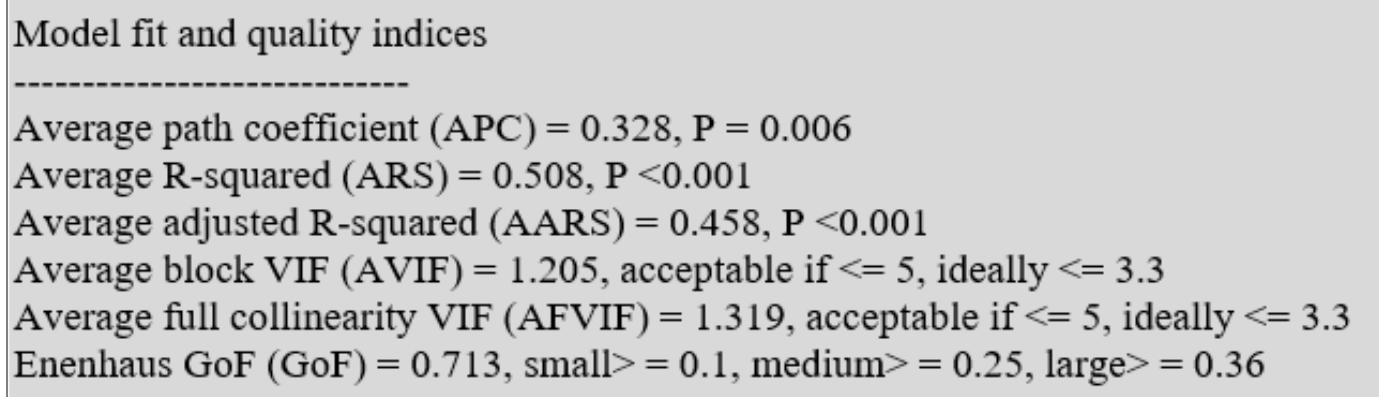

Fig. 1: Fit and Quality Indices Model. [Source: Processed Results of WarpPLS 6.0]

Table 1: Result of Weight Indicator Testing

\begin{tabular}{|l|c|c|c|c|c|c|c|c|}
\hline & PMA & PMDN & Government & $\begin{array}{c}\text { Economic } \\
\text { Growth }\end{array}$ & Poverty & Type & $\begin{array}{c}\text { P } \\
\text { Value }\end{array}$ & VIF \\
\hline PMA & 1,000 & 0.000 & 0.000 & 0.000 & 0.000 & Formative & $<0.001$ & 0.000 \\
\hline PMDN & 0.000 & 1,000 & 0.000 & 0.000 & 0.000 & Formative & $<0.001$ & 0.000 \\
\hline Government & 0.000 & 0.000 & 1,000 & 0.000 & 0.000 & Formative & $<0.001$ & 0.000 \\
\hline Economic & 0.000 & 0.000 & 0.000 & 1,000 & 0.000 & Formative & $<0.001$ & 0.000 \\
\hline Growth & & & & & & & & \\
\hline
\end{tabular}

Source: Processed Results of WarpPLS 6.0 
2. Block variance inflation factors

Output block variance inflation factors present the results of vertical collinearity testing, namely between predictor variables. The VIF value is presented for each criterion variable which indicates the level of collinearity or redundancy between the predictor variables. The results of vertical collinearity testing between predictor variables can be seen below Fig. 2 .

Fig. 2. shows the VIF value $<3.3$, so it can be concluded that the data does not experience collinearity problems.

\section{Hypothesis Test}

\section{a. First Stage Construction Testing Results}

The first stage of hypothesis testing will produce an equation without the role of the intervening variable, namely Economic Growth $\left(\mathrm{Y}_{1}\right)$ on the dependent variable, namely Poverty $\left(\mathrm{Y}_{2}\right)$. The first stage of construct testing will illustrate directly how the influence of the PMA $\left(\mathrm{X}_{1}\right)$, $\operatorname{PMDN}\left(\mathrm{X}_{2}\right)$, and Government investment $\left(\mathrm{X}_{3}\right)$ variables on poverty $\left(\mathrm{Y}_{2}\right)$.
Fig. 3. shows that the $\mathrm{R}$ - the square value of the influence of the foreign investment variable (X1), PMDN (X2), and government investment (X3) on the poverty variable (Y2) is 0.35 . These results indicate that $35 \%$ of poverty is influenced by the PMA, PMDN, and Government investment variables, and the remaining $65 \%$ is influenced by other variables. So, it can be concluded that the model is said to be feasible and has a relevant predictive value because the R-square value is greater than 0.05 or $5 \%$ indicating that the structural model has predictive relevance.

The significance of the estimated parameters provides information about the relationship between the research variables. The basis used in testing the hypothesis is the value contained in the output path coefficients as in Table 2.

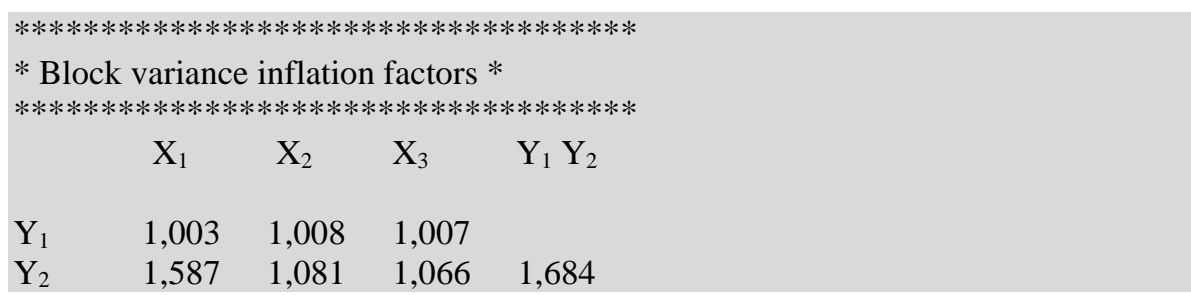

Fig. 2: Block Variance Inflation Factors. [Source: Processed Results of WarpPLS 6.0]

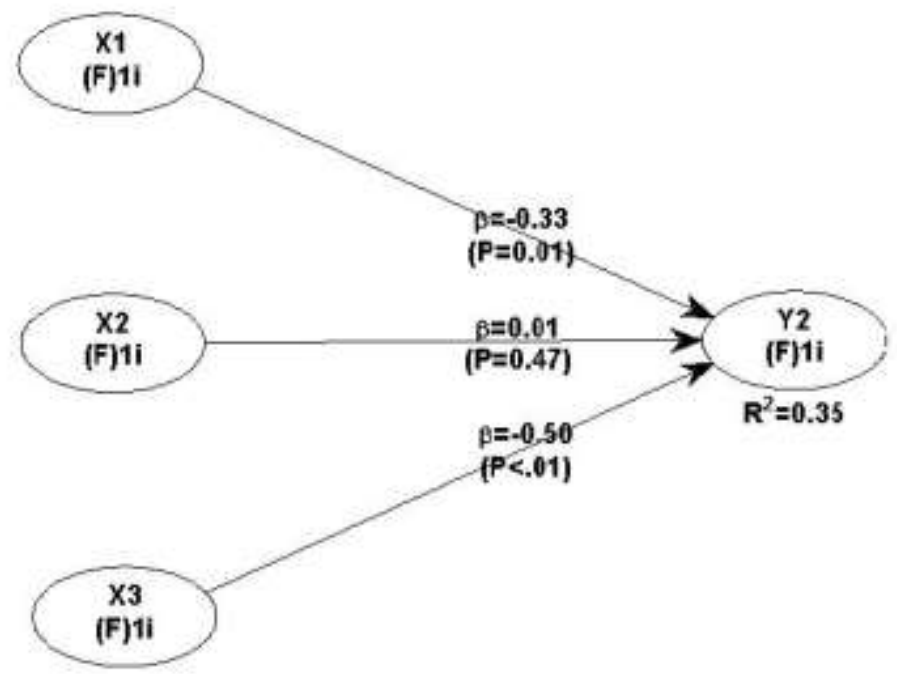

Fig. 3: Direct Effect Model Testing Results

Table 2: Direct Effect Model Testing Results

\begin{tabular}{|l|l|l|l|l|}
\hline Variable Relationships & Path Coefficients & $p$-value & Standard Error & Information \\
\hline $\mathrm{X}_{1} \rightarrow \mathrm{Y}_{2}$ & $-0,33$ & 0,01 & 0.158 & Significant \\
\hline $\mathrm{X}_{2} \rightarrow \mathrm{Y}_{2}$ & 0,01 & 0,47 & 0.154 & Not Significant \\
\hline $\mathrm{X}_{3} \rightarrow \mathrm{Y}_{2}$ & $-0,50$ & $<0,01$ & 0.136 & Significant \\
\hline
\end{tabular}

Source: Data Processing Using WarpPLS, 2020 


\section{Hypothesis 1}

Ha: There is a direct influence between foreign investment (PMA) on the poverty rate in Central Sulawesi

Based on the results of statistical testing of the Foreign Investment variable $\left(\mathrm{X}_{1}\right)$ on Poverty $\left(\mathrm{Y}_{2}\right)$, the path coefficient value is -0.33 with a value of $\rho(0.01) \leq 0.05$. These results indicate that there is a significant influence between foreign investment $\left(\mathrm{X}_{1}\right)$ on poverty $\left(\mathrm{Y}_{2}\right)$ so that the first hypothesis which states that there is a direct influence between foreign investment (PMA) on the poverty level in Central Sulawesi can be accepted.

The results of this study prove that foreign investment (PMA) that entered during the 2015 - 2019 period can reduce the poverty rate in Central Sulawesi, although the value of the realization of foreign investment during that period fluctuates.

\section{Hypothesis 2}

Ha: There is a direct influence between domestic investment $(P M D N)$ on the poverty rate in Central Sulawesi

Based on the results of statistical testing of the domestic investment variable $(\mathrm{PMDN})\left(\mathrm{X}_{2}\right)$ on poverty $\left(\mathrm{Y}_{2}\right)$, the path coefficient value is 0.01 with a value of $\rho(0.47)>0.05$. These results indicate that there is no significant influence between domestic investment $(\mathrm{PMDN})\left(\mathrm{X}_{2}\right)$ on poverty $\left(\mathrm{Y}_{2}\right)$ so that the second hypothesis which states that there is a direct influence between domestic investment (PMDN) on poverty levels in Central Sulawesi can be rejected. The results of this study illustrate that the decline in the value of domestic investment (PMDN) in Central Sulawesi during the 2018 - 2019 period did not affect the reduction in the poverty rate in that period. The poverty rate data in 2018 was $13.69 \%$, decreasing to $13.18 \%$ in 2019 .

\section{Hypothesis 3}

Ha: there is a direct influence between government investment on the poverty rate in Central Sulawesi

Based on the results of statistical testing of the Government Investment variable $\left(\mathrm{X}_{3}\right)$ on Poverty $\left(\mathrm{Y}_{2}\right)$, the path coefficient value is -0.50 with a value of $\rho(0.01) \leq 0.05$. These results indicate that there is a significant influence between Government Investment $\left(\mathrm{X}_{3}\right)$ on Poverty $\left(\mathrm{Y}_{2}\right)$, so that the third hypothesis which states that there is a direct influence between Government investment $\left(\mathrm{X}_{3}\right)$ on the poverty level in Central Sulawesi can be accepted. The results of this study indicate that the allocation of government spending has been able to reduce the poverty rate in Central Sulawesi, even though the value of government investment during the 2015-2018 period continued to decline. During the 2015-2019 period, many government spending was allocated as a source of funding for poverty alleviation programs in the form of services to the poor, such as health, education, public facilities, and social protection, so that it greatly helped the poor to improve their welfare.

\section{b. Second Stage Construction Testing Results}

The second stage of hypothesis testing will produce an equation with the role of the intervening variable, namely economic growth $\left(\mathrm{Y}_{1}\right)$ on the dependent variable, namely poverty $\left(\mathrm{Y}_{2}\right)$. The second stage of construct testing will illustrate indirectly how the influence of the foreign investment variable $\left(\mathrm{X}_{1}\right), \operatorname{PMDN}\left(\mathrm{X}_{2}\right)$ and government investment $\left(\mathrm{X}_{3}\right)$ on poverty $\left(\mathrm{Y}_{2}\right)$ through economic growth $\left(\mathrm{Y}_{1}\right)$.

The second stage of structural model testing was carried out to see the relationship between the constructs of significant value and predictive-relevance $\left(\mathrm{Q}^{2}\right)$. Value predictiverelevance $\left(\mathrm{Q}^{2}\right)$ has the same meaning as the coefficient of determination (R-square $/ \mathrm{R}^{2}$ ). Statistically testing each hypothesized relationship is done using a simulation.

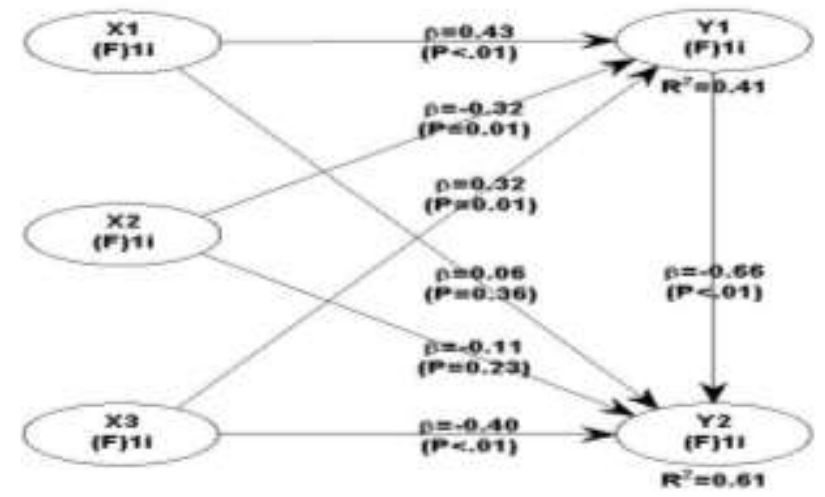

Fig. 4: Indirect Effect Model Testing Results

Fig. 4. shows the R-square value of the influence of the PMA investment variable $\left(\mathrm{X}_{1}\right), \operatorname{PMDN}\left(\mathrm{X}_{2}\right)$ and Government investment $\left(\mathrm{X}_{3}\right)$ on the economic growth variable $\left(\mathrm{Y}_{1}\right)$ of 0.41 and the $\mathrm{R}$-square value of the influence of the PMA investment variable $\left(\mathrm{X}_{1}\right)$, PMDN $\left(\mathrm{X}_{2}\right)$, Government investment $\left(\mathrm{X}_{3}\right)$, economic growth $\left(\mathrm{Y}_{1}\right)$ against poverty $\left(\mathrm{Y}_{2}\right)$ is 0.61 .

Based on Fig. 4, the predictive-relevance $\left(\mathrm{Q}^{2}\right)$ value can be determined by the following formula:

$\mathrm{Q}^{2}=1-\left(1-\mathrm{R}_{1}{ }^{2}\right)\left(1-\mathrm{R}_{2}{ }^{2}\right)$

$\mathrm{Q}^{2}=1-(1-0.41)(1-0.61)$

$\mathrm{Q}^{2}=1-0.2301$

$\mathrm{Q}^{2}=0.7699$, rounding to 0.77 .

In this research model, the total R-square value produced is 0.77 , meaning that the percentage of influence that can be explained by the model is $77 \%$, while the remaining $23 \%$ is influenced by other factors. So it can be concluded that the model is said to be feasible and has a relevant predictive value because the Q- square value is greater than 0.05 or $5 \%$ indicating that the structural model has predictive relevance. 
Table 3: Results of Testing Indirect and total effects

\begin{tabular}{|l|l|l|l|l|}
\hline Variable Relationships & Path Coefficients & p-value & Standard Error & Information \\
\hline $\mathrm{X}_{1} \rightarrow \mathrm{Y}_{1} \rightarrow \mathrm{Y}_{2}$ & $-0,285$ & 0,004 & 0.134 & Significant \\
\hline $\mathrm{X}_{2} \rightarrow \mathrm{Y}_{1} \rightarrow \mathrm{Y}_{2}$ & 0,211 & 0,025 & 0.141 & Significant \\
\hline $\mathrm{X}_{3} \rightarrow \mathrm{Y}_{1} \rightarrow \mathrm{Y}_{2}$ & $-0,213$ & 0,025 & 0.141 & Significant \\
\hline
\end{tabular}

Source: Data Processing Using WarpPLS, 2020

Further testing is needed to determine whether there is an indirect effect (Indirect Effect) of Foreign Investment $\left(\mathrm{X}_{1}\right)$, Private Investment $\left(\mathrm{X}_{2}\right)$, Government Investment $\left(\mathrm{X}_{3}\right)$ on Poverty $\left(\mathrm{Y}_{2}\right)$ through economic growth $\left(\mathrm{Y}_{1}\right)$. statistically significant. The significance of the estimated parameters provides information about the relationship between the research variables. The basis used in testing the hypothesis is the value contained in Indirect and total effects as in Table 3.

\section{Hypothesis 4}

Ha: There is an indirect effect between foreign investment (PMA) on poverty levels through economic growth in Central Sulawesi

Based on Figure 4, it is known that the value of the path coefficient of the influence of the Foreign Investment variable $\left(\mathrm{X}_{1}\right)$ on Poverty $\left(\mathrm{Y}_{2}\right)$ through Economic Growth $\left(\mathrm{Y}_{1}\right)$ is -0.285 with a value of $\rho(0.004) \leq 0.05$. These results indicate that there is a significant influence between Foreign Investment $\left(\mathrm{X}_{1}\right)$ on Poverty $\left(\mathrm{Y}_{2}\right)$ through Economic Growth $\left(\mathrm{Y}_{1}\right)$, so that the fourth hypothesis which states that there is an indirect effect between foreign investment (PMA) on poverty levels through Economic Growth in Central Sulawesi is acceptable.

\section{Hypothesis 5}

Ha: There is an indirect effect between domestic investment $(P M D N)$ on poverty levels through economic growth in Central Sulawesi

Based on Figure 4, it is known that the path coefficient value of the influence of the domestic investment variable (PMDN) $\left(\mathrm{X}_{2}\right)$ on poverty $\left(\mathrm{Y}_{2}\right)$ through economic growth $\left(Y_{1}\right)$ is 0.211 with a value of $\rho(0.025)>0.05$. These results indicate that there is a significant influence between Domestic Investment (PMDN) $\left(\mathrm{X}_{2}\right)$ on Poverty $\left(\mathrm{Y}_{2}\right)$ through Economic Growth $\left(\mathrm{Y}_{1}\right)$, so the fifth hypothesis which states that there is an indirect effect between domestic investment (PMDN) on the level of poverty through Economic Growth in Central Sulawesi is acceptable.

\section{Hypothesis 6}

Ha: There is an indirect effect between government investment on poverty levels through economic growth in Central Sulawesi

Based on Fig. 4, it is known that the path coefficient value of the influence of the Government Investment variable $\left(\mathrm{X}_{3}\right)$ on Poverty $\left(\mathrm{Y}_{2}\right)$ through Economic Growth $\left(\mathrm{Y}_{1}\right)$ is -0.213 with a value of $\rho(0.025) \leq 0.05$. These results indicate that there is a significant influence between Government Investment $\left(\mathrm{X}_{3}\right)$ on Poverty $\left(\mathrm{Y}_{2}\right)$ through Economic Growth $\left(Y_{1}\right)$, so that the sixth hypothesis which states that there is an indirect effect between Government investment on poverty levels through Economic Growth in Central Sulawesi can be accepted.

\section{Discussion}

1. The direct effect of foreign investment (PMA) on poverty levels in Central Sulawesi

The test results of the first hypothesis show that the direct effect of foreign investment (PMA) on poverty has a significant effect on the Path coefficient value of the PMA investment variable of -0.33 . Statistically, it can be explained that if there is an increase in the value of the foreign investment by 1 unit, it will have a negative effect on the poverty rate by -0.33 units. This means that if there is an increase in the amount of foreign investment, it will decrease the poverty rate in Central Sulawesi Province. The results of this study are in line with the data on the realization of foreign direct investment for the 2015-2019 period, which always fluctuates and tends to increase during the study period. The increase in the amount of foreign investment was also followed by a decrease in the number of poverties in Central Sulawesi.

This study is by following research conducted by Lim Guech Heang and Pahlaj Moolio (2013), which states that PMA affects poverty reduction in Cambodia. Other research was also conducted by Ogunniyi and Igberi (2014) in Nigeria which shows that PMA has a positive impact on real per capita income and therefore has the potential to reduce poverty in Nigeria.

Various policies have been taken by the local government to reduce poverty in Central Sulawesi, one of which is the investment route. This policy includes promotions to attract domestic and foreign investors with the issuance of the investment law in 1966. With more and more investment coming in, it will open up new jobs and provide wider opportunities for people in Central Sulawesi.

Most of the foreign investment made by foreign countries in Central Sulawesi Province is in the mining sector. These companies have a capital-intensive production factor, so the investments they invest in Central Sulawesi follow the 
techniques they have developed or applied in their home countries, which tend to be capital intensive. The existence of these mining companies provides direct economic benefits through tax revenue and job creation. The indirect benefits of a mining company include the circulation of goods and services, infrastructure development, and the emergence of supporting businesses (mining locations will create supporting businesses to supply food, clothing, and food for employees).

\section{The direct effect of domestic investment (PMDN) on poverty levels in Central Sulawesi}

Analysis of the effect of domestic investment on poverty shows that domestic investment (PMDN) has no significant effect on reducing poverty in Central Sulawesi Province. One of the reasons for the absence of the effect of PMDN on reducing poverty in Central Sulawesi Province is due to the very small investment value of PMDN which tends to decline during the study period, as well as the priority of investing more in the infrastructure and energy supply sectors. These sectors absorb very little workforce. These projects are short-term projects and cannot accommodate a large number of local workers over a long period of time.

This is very reasonable because the investment value plays a very important role in supporting and accelerating the growth of employment that has a high absorption capacity of labor so that it can help the government in overcoming labor problems. The greater the value of the investment in PMDN, the more workers will be absorbed in Central Sulawesi Province, and vice versa.

Domestic investment realized in Central Sulawesi Province tends to invest in the infrastructure sector and provide more energy for capital-intensive economic activities and not people's economic activities (labor-intensive), causing investment to not absorb labor optimally so that it correlates to increase the poverty line in Central Sulawesi.

The results are consistent with research conducted by Wardani et al. (2014) in his research entitled on Analysis of Effect of domestic and foreign investments to the GDP in Siak district. The results showed that partially, PMDN investment had a negative effect on Siak's GDP during the 2003-2012 period. Furthermore, the research results of Wardani et al. (2014) also concluded that the use of investment from 2003-2012 was not fully efficient. This means that the investment cannot be used optimally in investment activities.

Another study by Marsoit et al. (2015) which examined the effect of private investment and capital spending on poverty in Manado City in 2004-2012 also concluded that private investment had no effect on poverty. This is because investment in the city of Manado is only capital intensive which tends to use high technology and requires high human resources to use the technology used.

\section{The direct effect of government investment on poverty levels in Central Sulawesi}

Based on the results of statistical testing of the Government Investment variable on Poverty, the path coefficient value is -0.50 with a value of $\rho(0.01) \leq 0.05$, which means that if there is an increase in the value of Government investment by 1 unit it will reduce the poverty level by $-0,50$ units. The results of this study prove statistically the significant effect of government investment on reducing poverty in Central Sulawesi Province. This means that if there is an increase in the amount of local government spending, the poverty rate in Central Sulawesi Province will decrease.

The reduction in the poverty rate was the result of a regional government policy through increasing the flow of funds to the community through direct spending which affected the welfare of the community and was able to reduce the number of poor people or the percentage of poor people in Central Sulawesi Province. There is a commitment from the local government in prioritizing public investment through the ratio of local government capital expenditures to total district/city and provincial government spending in Central Sulawesi.

Capital spending has a relatively large direct impact on the economy. Although in general, the share of government investment is smaller than private investment, its role is irreplaceable in an economy. The development of public infrastructures such as roads, irrigation canals, and electricity networks requires the role of the government. The role of government investment is increasingly important in regions with relatively low levels of private investment. Government investment in this context acts as a pioneer and paves the way for the entry of private investment.

The increase in public service capital expenditures by the Province of Central Sulawesi can spur efforts to increase the availability of various regional infrastructures that are capable of encouraging the economic activity of the community/ population (including the rural poor) and ultimately encouraging economic growth and a shift in the economic structure of the community, even being able to provide new jobs (employment opportunities) so that people's income can also increase as an indicator of welfare as well as an indicator of decreasing poverty levels (number of poor people).

Government capital expenditures are generally allocated to build facilities and infrastructure which in turn will increase the intensity of economic activity. The increase in economic activity is then expected to encourage economic growth which in turn will improve the welfare of the community. An increase in the amount of local government capital expenditure has a positive impact on the poor because the availability of adequate infrastructure is a positive impact of an increase in regional government capital expenditure 
which will make it easier for people to carry out economic and social activities which will then improve people's welfare so that it can reduce poverty levels.

The results of this study are consistent with research conducted by Hendarmin (2012), who researched the effect of local government capital expenditures and private investment on economic growth, employment opportunities, and community welfare in districts/cities of West Kalimantan Province. The results of his research show that local government capital expenditures, although not significant, affect economic growth, which in turn can improve people's welfare and reduce poverty.

\section{The indirect effect of foreign investment (PMA) on poverty levels through economic growth in Central Sulawesi}

The test results show the path analysis coefficient values track variables influence the Foreign Investment on Poverty through Economic Growth is of -0.285 with $\rho(0,004) \leq$ 0.05. This means that an increase in the value of PMA investment by 1 unit through economic growth will have a negative and significant effect on the poverty level of -0.285 units. The results of this study prove that economic growth partially mediates the effect of FDI on poverty through economic growth in Central Sulawesi. Partially, foreign investment has a positive and significant impact on economic growth in Central Sulawesi Province. The increase in foreign investment will trigger an increase in economic growth because an increase in foreign investment indicates an increase in investment or capital formation.

Hypothesis testing of the mediating effect (Intervening) on the effect of foreign investment (PMA) on poverty through economic growth is done by estimating the indirect effect model, showing that the effect of foreign investment on poverty through economic growth has a significant effect. This shows the support that economic growth partially mediates the effect of foreign investment on poverty. The results of this study prove that any increase in the value of foreign investment through economic growth will reduce the level of poverty in Central Sulawesi Province.

The increase in foreign investment (PMA) will result in an increase in the production of goods and services in the economy, increase the active role of the community in economic activities and expand employment and employment opportunities. Increasing the production of goods and services, employment opportunities, and employment will have an impact on increasing the purchasing power of the people, to increase economic growth in Central Sulawesi.

The results of this study are consistent with the research of Hemmer, HR, and Phuong Hoa (2002) which shows that PMA affects job creation. Further analysis of the indirect impact of FDI through economic growth also shows that there is a significant influence on the contribution of FDI to regional budgets. Nizar et al. (2013) also concluded that PMA has a positive and significant effect on economic growth and that there is a direct effect of economic growth on poverty levels.

The increase in economic growth also shows that more workers are absorbed, and vice versa. The massive expansion in the opening and processing of mining has an impact on the increasing absorption of labor in this sector. Mining businesses in Morowali, North Morowali, and Luwuk Regencies are not only owned by large companies (corporate) but are also operated and owned by the people (people's mines). As a result, in the areas surrounding mining development, centers of economic growth in rural areas have emerged. This condition has increased the purchasing power of rural communities, especially for routine household needs. The circulation of money that occurs at the location in the long term can stimulate economic growth in this region by growing trade and services. This means that mining activities create a multiplier effect, especially in employment and business opportunities.

\section{The indirect effect of domestic investment (PMDN) on poverty levels through economic growth in Central Sulawesi}

The test results of the Direct Effect Model and the Indirect Effect model between the PMDN variables on poverty show that there is no significant effect of PMDN on reducing the poverty rate in Central Sulawesi Province. However, analysis of the indirect effect of domestic investment (PMDN) on poverty through economic growth shows a significant effect, while partially PMDN investment has a positive and significant impact on economic growth in Central Sulawesi. The increase in domestic investment (PMDN) results in an increase in the production of goods and services in the economy.

This is shown by the path coefficient value of the influence of the domestic investment variable (PMDN) on poverty through economic growth of 0.211 with a value of $\rho$ $(0.025)>0.05$. The results of this study indicate that an increase in PMDN investment will trigger an increase in economic growth in Central Sulawesi because an increase in investment indicates an increase in investment or capital formation.

Hypothesis testing mediation effects (intervening) influence on domestic investment (DCI) against poverty through economic growth that is done by estimating the model indirect effect showed the significant influence between domestic investment to economic growth in Central Sulawesi province. This shows that economic growth partially mediates the effect of PMDN on poverty levels in Central Sulawesi. The results of this study prove that every increase in PMDN investment through economic growth 
will reduce the level of poverty in Central Sulawesi Province.

This increase in the production of goods and services has led to an increase in economic growth in Central Sulawesi Province. Conversely, if there is a decrease in investment, then the GRDP will also decrease because the decrease in investment indicates a decrease in investment or capital formation. A decrease in investment or capital formation will result in a decrease in the production of goods and services. A decrease in the production of goods and services will cause a decline in economic growth. The findings of this study are supported by the opinion of Harrod Domar who stated that in supporting economic growth, new investment investments are needed as capital stocks. The more savings that are then invested, the faster the economic growth will occur.

PMDN investment activities also affect economic activities and job opportunities, thereby increasing regional income, which in turn improves the welfare of the community. Previous studies have proven that an increase in PMDN investment can increase the economic growth of a region. The results of statistical testing on the second hypothesis show that the greater the level of PMDN investment, the higher the economic growth will be. The results of this study are consistent with the research of Yetty and Erni (2017) which shows that domestic investment (PMDN) has a positive and significant effect on economic growth. The results of this study are also supported by research by Pambudy and Syairozi (2019) which concludes that private investment has a significant effect on economic growth and increases the welfare of the people in Indonesia during the study period. The significant influence of investment (PMDN) on labor absorption is by following per the theory of Sukirno (2012b) that investment activities allow people to continuously increase economic activities and job opportunities, increase national income and increase the level of community welfare.

The role of the private sector in investing its capital in districts/cities in Indonesia has provided wide employment opportunities for the community, thereby increasing the level of community income which has an impact on increasing the value of GRDP. Economic development encourages economic growth because it increases economic activity, opens up job opportunities, which has an impact on increasing people's income. If people's income increases, then the community can improve their quality of life by fulfilling their basic needs, namely the need for education and health need. So that if people's income can be increased, the level of community welfare will increase.

The indirect effect of government investment on poverty levels through economic growth in Central Sulawesi.
The results of testing the direct effect model between government investment variables on poverty show that there is a direct effect of government investment on poverty. Hypothesis testing of the effect of mediation (intervening) on the effect of government investment on poverty through economic growth which is done by estimating the indirect effect model also shows a significant effect. The results of this study prove that any increase in government investment through economic growth will reduce the level of poverty in Central Sulawesi Province.

This shows that direct expenditure reflected in local government spending has a negative effect on poverty levels. This means that the higher the APBD allocation for poverty alleviation and reduction programs, the lower the level of poverty in the community.

Partially, government investment also has a significant effect on economic growth in Central Sulawesi Province. This indicates that economic growth in Central Sulawesi is also determined by government investment. An increase in government investment during the 2015-2019 period has affected economic growth through the development of public infrastructure in the regions to encourage increased production of goods and services. The findings of this study agree with Freadgold (1996) which states that government spending affects GDP growth. Furthermore, Freadgold stated that changes in government spending are influenced by regional government policies themselves.

This study supports the research of Paseki MG, et al., (2014) in their research entitled the effect of general allocation funds and direct expenditure on economic growth and its impact on poverty in Manado City in 2004-2012. Research that uses path analysis to analyze the influence between variables, concludes that there is a direct effect of the General Allocation Fund (DAU) and direct spending on reducing poverty levels in the city of Manado.

The results of this test support the research of Putrayuda et al. (2017) which examines the effect of local revenue (PAD), general allocation funds (DAU), revenue sharing (DBH) and capital expenditures on economic growth and their impact on poverty levels in regencies / cities. Riau Province 2011-2015. Using the Partial Least Square (PLS) analysis method, this study concludes that capital expenditure has a significant effect on poverty levels and economic growth as a mediating variable (intervening) which plays an important role in increasing the effect of capital spending on poverty levels.

\section{Conclusion}

Based on the description of the discussion above, it can be concluded:

1. There is a direct influence between foreign investment (PMA) on poverty levels in Central Sulawesi. 
2. There is a direct influence between domestic investment (PMDN) on poverty levels in Central Sulawesi.

3. There is a direct influence between government investment on poverty levels in Central Sulawesi.

4. There is an indirect effect between foreign investment (PMA) on poverty levels through economic growth in Central Sulawesi.

5. There is an indirect effect between domestic investment (PMDN) on poverty levels through economic growth in Central Sulawesi.

6. There is an indirect effect between government investment on poverty levels through economic growth in Central Sulawesi.

\section{Suggestions}

Efforts to increase economic growth and reduce poverty in Central Sulawesi, it is suggested:

1. Creating a conducive social, political, legal, and bureaucratic system so that it can attract more investors to invest in Central Sulawesi.

2. Investment realization is directly correlated with economic programs to alleviate poverty, meaning that investment is channeled to several sectors that touch unemployment and poverty rates.

3. The role of local governments is active and maximal in supporting service institutions that are responsible and directly authorized for investment, so that proactive programs that promote regional excellence become investment attractions.

4. Local government policies are needed to maximize the absorption of local labor compared to workers from outside the region and foreign workers. Maximizing the use of Corporate Social Responsibility (CSR) funds by local governments by entering CSR funds into the body of the APBD, so that the realization of the use of Corporate Social Responsibility (CSR) funds can be directly correlated with economic programs to alleviate poverty.

\section{References}

Arsyad L (2010) Introduction to Regional Economic Planning and Development, Third Edition, BPFE, Yogyakarta

BKPM RI (2017) Realization of PMDN AND PMA Investment, Jakarta.

Bouchoucha N and Bakari S (2019) The Impact of Domestic and Foreign Direct Investment on Economic Growth: Fresh Evidence from Tunisia. MPRA Paper No. 94777.

Central Bureau of Statistics (BPS) (2003) Poverty Data and Information for 2003. Jakarta

Deswantoro DB et al. (2017) The Influence of Regional Expenditure Based on Economic Classification on Economic Growth and Community Welfare in Regencies / Cities of West Kalimantan Province in 2010 - 2015.
Journal of Business Economics and Entrepreneurship, 6(3): $187-210$.

Dumairy (2006) The Indonesian Economy. Jakarta: Erlangga

Ebunoluwa OO and Yusuf WA (2018) Effects of Economic Growth on Poverty Reduction in Nigeria. IOSR Journal of Economics and Finance (IOSR-JEF) 9(5): 25-29.

Freedgold, ML 1996. Macroeconomic Policy Issues in the Asia Pacific Economy (translated edition) Prentice Hall.

Hemmer HR and Phuong H 2002. Contribution of Foreign Direct Investment to Poverty Reduction: The Case of Vietnam in the 1990s. Entwicklungsökonomische Diskussionsbeiträge, No. 30. Justus Liebig University Giessen, Institute for Development Economics

Hendarmin (2012) The Influence of Local Government Capital Expenditures and Private Investment on Economic Growth, Job Opportunities and Community Welfare in Regencies / Cities of West Kalimantan Province. Journal of the Faculty of Economics and Business, JEKSOS 8(3): $144-155$.

Kuncoro M (2006) Development Economics: Theory, Problems, and Policy. Yogyakarta: UPP STIM YKPN

Lailan S and Sri Endang R (2011) Analysis of the Influence of Public and Private Investments on the Creation of Job Opportunities in North Sumatra. Journal of Management \& Business 11(1)

Lim GH and Pahlaj M (2013) The Relationship between Gross Domestic Product and Foreign Direct Investment: The Case of Cambodia. KASBIT Business Journal 6: 87-99.

Marsoit C et al. (2015) The Effect of Private Investment and Capital Expenditures on Poverty in the City of Manado, 2004-2012. Periodic Scientific Journal of Efficiency 15(1): 1-13.

Nizar C, Hamzah A and Syahnur S (2013) The Influence of Investment and Labor on Economic Growth and Its Relationship to Poverty Levels in Indonesia. Journal of Economics 1(2): 1-8.

Nosheen M (2013) Impact of Foreign Direct Investment on Gross Domestic Product. World Applied Sciences Journal 24(10): 1358-1361.

Ogunniyi BM and Igberi OC (2014) The Impact of Foreign Direct Investment (FDI) on Poverty Reduction in Nigeria. Journal of Economics and Sustainable Development 5(14).

Pambudy AP and Syairozi MI (2019) Analysis of the Role of Capital Spending and Private Investment on Economic Growth and its Impact on Community Welfare. ECOBIS Journal 20(1): 26 -39.

Paseki MG, et al. 2014. The Effect of General Allocation Funds and Direct Expenditures on Economic Growth and Its Impact on Poverty in Manado City in 2004-2012. Periodic Scientific Journal of Efficiency 14(3): 30-42.

Putrayuda TF et al. (2017) Analysis of the Effect of Local Own Revenue (PAD), General Allocation Funds (DAU), 
Revenue Sharing Funds (DBH) and Capital Expenditures on Economic Growth and Its Impact on Poverty Levels in Regencies / Cities of Riau Province in 2011-2015. Journal of Business Management Tepak 9(3): 198-224.

Rabnawaz A and Jafar RM (2015) Impact of Public Investment on Economic Growth. $S$ outh Asia Journal of Multidisciplinary Studies (SAJMS) 1(8): 62-75.

Sukirno S (2012a) Introductory Macroeconomic Theory (3rd Eds). Jakarta: Rajawali Press.

Sukirno S (2012b) Modern Macro Economics. The Development of Thought From Classical to New Keynesian. Rajawali Press, Jakarta

Syahputra R (2017) Analysis of factors affecting economic growth in Indonesia. Journal of Ocean Economics 1(2); 183-191.

Untoro J (2010) Macro Economics. Jakarta: Kawah Media.
Wardani W, Kornita S, Taryono. 2014. Analysis of the Effect of PMDN \& PMA on PDRB in Siak Regency. JOM Fekon 2(1): 1-18.

Yetty A and Erni PK (2017) The Influence of Domestic Investment, Foreign Direct Investment, and Labor Absorption on Economic Growth and the Number of Poor People in Districts / Cities in West Kalimantan Province. Journal of Business Economics and Entrepreneurship 6(2): 97-119.

Yuliarti (2020) The Effect of Local Government Expenditure Realization on Economic Growth in West Sumatra. Journal of Education on Social Science 4(1): 136- 147.

Yuniarto PR (2014) Globalization Problems in Indonesia: Between Interests, Policies and Challenges. Journal of Regional Studies 5(1): 67-95 